\title{
GAYA BELAJAR DAN MATHEMATICS SELF-CONCEPT TERHADAP MINAT AKADEMIK MAHASISWA
}

\author{
Nita Delima1, Yanry Budianingsih² \\ 1,2 Universitas Subang, Jl. R.A. Kartini Km 3 Subang, Indonesia \\ Email: nitadelima1985@gmail.com
}

\begin{abstract}
The study style and Mathematics Self-Concept (MSC) can be a strong predictor of making choices on the education and work of a person. Meanwhile, the student's academic interest in the course he selected currently affects the student's academic achievement. The study aims to determine if there is a significant influence on the learning style of student academic interests in the course of study. In addition, the study also aims to determine if there is a significant effect on MSC in student academic interest in the course of study. The learning style examined in this study is Kolb's learning style. This research is an associative descriptive study with a quantitative approach. Data collection is done by using instruments to measure learning style in the form of Learning Style Inventory (LSI), as well as poll to measure MSC. The results of this study revealed that there was no significant influence on the learning style of student academic interests in the course of study. However, the learning styles that have been measured in this study can be used to determine methods, techniques and learning strategies suitable for each student. In addition, the study also found that there was a significant influence on MSC in student academic interest in the course of study. This gives the implication that MSC can be a predictor of someone in choosing the education he is asked for.
\end{abstract}

Keywords: Learning styles, mathematics self-concept, academic interest

\begin{abstract}
ABSTRAK
Gaya belajar dan Mathematics Self-Concept (MSC) dapat menjadi prediktor yang kuat dalam melakukan pilihan terhadap pendidikan dan pekerjaan seseorang. Sementara itu, minat akademik mahasiswa pada program studi yang dipilihnya saat ini mempengaruhi pada pencapaian prestasi akademik mahasiswa. Penelitian ini bertujuan untuk mengetahui apakah terdapat pengaruh signifikan gaya belajar terhadap minat akademik mahasiswa pada pemilihan program studi. Selain itu, penelitian ini juga memiliki tujuan untuk mengetahui apakah terdapat pengaruh signifikan MSC terhadap minat akademik mahasiswa pada pemilihan program studi. Gaya belajar yang diteliti dalam penelitian ini adalah gaya belajar Kolb. Penelitian ini merupakan penelitian deskriptif asosiatif dengan pendekatan kuantitatif. Pengumpulan data dilakukan dengan menggunakan instrumen untuk mengukur gaya belajar berupa angket Learning Style Inventory (LSI), serta angket untuk mengukur MSC. Hasil penelitian ini mengungkapkan bahwa tidak terdapat pengaruh yang signifikan gaya belajar terhadap minat akademik mahasiswa pada pemilihan program studi. Meskipun demikian, gaya belajar yang telah diukur dalam penelitian ini dapat digunakan untuk menentukan metode, teknik serta strategi belajar yang cocok untuk setiap mahasiswa. Selain itu, penelitian ini juga menemukan bahwa terdapat pengaruh yang signifikan MSC terhadap minat akademik mahasiswa pada pemilihan program studi. Hal tersebut memberikan implikasi bahwa MSC dapat menjadi prediktor seseorang dalam memilih pendidikan yang diminatinya.
\end{abstract}

Kata kunci: Gaya belajar, mathematics self-concept, minat akademik

Dikirim: 15 Februari 2020; Diterima: 18 Februari 2020; Dipublikasikan: 30 Maret 2020

Cara sitasi: Delima, N., \& Budianingsih, Y. (2020). Gaya belajar dan mathematics self-concept terhadap minat akademik mahasiswa. Teorema: Teori dan Riset Matematika, 5(1), 1-8. 


\section{PENDAHULUAN}

Pemilihan program studi mahasiswa menunjukkan minat akademik mahasiswa tersebut. Minat pada dasarnya adalah penerimaan akan suatu hubungan antara diri sendiri dengan sesuatu di luar diri. Semakin kuat atau dekat hubungan tersebut, semakin besar minat. Slameto (2010) menyatakan bahwa minat adalah suatu rasa lebih suka dan rasa ketertarikan pada suatu hal tanpa ada yang menyuruh. Siswa yang memiliki minat terhadap bidang keilmuan tertentu cenderung untuk memberikan perhatian yang besar terhadap keilmuan tersebut. Hal tersebut berimbas pada minat akademik mereka saat memilih program studi di perguruan tinggi. Dengan demikian, ketepatan pemilihan program studi dengan minat akan mendukung pada pencapaian prestasi akademik mahasiswa.

Karakteristik setiap mahasiswa dalam belajar dapat menentukan suatu stimulan yang tepat untuk memperoleh pembelajaran yang optimal. Sebagaimana yang dikemukakan oleh Pratiwi et.al (2010) bahwa apabila seseorang dipaksa mempelajari sesuatu dengan metode yang bukan gaya belajarnya, orang tersebut dapat merasa tertekan dan frustasi. Apabila mahasiswa memahami gaya belajarnya sendiri, maka akan lebih mudah bagi mereka dalam mempelajari sesuatu. Gaya belajar yang diteliti dalam penelitian ini adalah gaya belajar yang diusung oleh David A. Kolb yang kemudian diistilahkan sebagai gaya belajar Kolb. Menurut Kolb et.al (2000) bahwa gaya belajar dibagi menjadi empat gaya, yaitu: (1) gaya eksplorasi (diverging), individu dengan gaya eksplorasi menyukai melihat fenomena berdasarkan perspektif yang majemuk; (2) gaya asimilasi (assimilating), individu dengan gaya asimilasi senantiasa memahami permasalahan secara luas kemudian disimpulkan; (3) gaya pemusatan (converging), individu dengan gaya ini menyukai mencari sisi-sisi praktis dari teori atau gagasan; dan (4) gaya akomodasi (accommodating), individu dengan gaya ini mengutamakan pada eksplorasi pengalaman-pengalaman yang menantang. Kolb \& Kolb (2005) mengemukakan bahwa selama tiga dekade terakhir ini, para peneliti telah menemukan konsistensi antara gaya belajar dengan sejumlah variabel lainnya, seperti tipe kepribadian, spesialisasi pendidikan, karir profesional, peran dalam pekerjaan, serta kompetensi penyesuaian diri. Kaminski et.al (2005) menemukan bahwa terdapat hubungan yang signifikan antara tingkatan kelas dengan gaya belajar. Gaya belajar dapat dijadikan sebagai acuan untuk memilih metode, teknik dan strategi dalam belajar (Cimermanova, 2018).

Hasil penelitian yang dilakukan oleh Marsh \& Hau (2003), Marsh (2005), Liu et.al (Adegoke, 2015) menemukan bahwa kemampuan akademik siswa memiliki hubungan yang positif dan signifikan dengan academic self-concept yang mereka miliki. Marsh \& Shavelson (Adegoke, 2015) membagi academic self-concept menjadi dua domain, yakni verbal self-concept dan mathematics self-concept. Dunia pendidikan saat ini umumnya menggunakan Mathematics Self-Concept (MSC) untuk melihat prestasi siswanya. Marsh (Githua \& Mwangi, 2003) mendefinisikan Mathematics Self-Concept (MSC) sebagai persepsi seseorang terhadap dirinya sendiri mengenai kemampuan dan keterampilan matematiknya, kesenangan dan ketertarikan dalam melakukan kegiatan matematika. Marsh \& Hau (2003), Marsh (2005), Liu et.al (Adegoke, 2015) menyatakan bahwa kognisi yang terkait dengan kemampuan berpikir dan perasaan positif tentang dirinya sendiri dapat memberikan keuntungan dalam mengambil pilihan, merencanakan dan prestasinya di kemudian hari. Hal tersebut, diperkuat oleh penelitian Nagy et.al (2010) yang mengatakan bahwa MSC dapat menjadi prediktor yang kuat dari prestasi sekolah serta dalam melakukan pilihan pendidikan dan pekerjaan.

Beberapa penelitian mengemukakan bahwa gaya belajar merupakan salah satu faktor yang mempengaruhi keberhasilan pembelajaran (Chen et.al, 2015; Kamuche, 2011; Wilkinson et.al, 2013; Kaminski et.al, 2005). Berdasarkan uraian di atas, MSC dapat menjadi prediktor yang kuat untuk melihat prestasi seseorang. Sementara itu, minat akademik mahasiswa pada program studi yang 
dipilihnya saat ini mempengaruhi pada pencapaian prestasi akademik mahasiswa. Oleh karena itu, terdapat dugaan bahwa gaya belajar dan MSC mempengaruhi minat akademik mahasiswa pada pemilihan program studi. Penelitian ini bertujuan untuk mengetahui apakah terdapat pengaruh yang signifikan gaya belajar terhadap minat akademik mahasiswa pada pemilihan program studi. Selain itu, penelitian ini juga memiliki tujuan untuk mengetahui apakah terdapat pengaruh yang signifikan MSC terhadap minat akademik mahasiswa pada pemilihan program studi.

\section{METODE PENELITIAN}

Penelitian ini merupakan penelitian deskriptif dan asosiatif, dengan pendekatan kuantitatif. Penelitian ini melibatkan tiga variabel, yakni dua variabel bebas dan satu variabel terikat. Variabel bebas dari penelitian ini adalah gaya belajar dan Mathematics Self-Concept (MSC), sedangkan variabel terikatnya adalah minat akademik mahasiswa. Minat akademik mahasiswa yang dimaksud dalam penelitian ini adalah program studi yang menjadi homebased mahasiswa dalam menempuh jenjang sarjana. Penelitian ini berlangsung di beberapa Universitas di Indonesia, diantaranya Universitas Subang dan Universitas Muhammadiyah Bandung. Sementara itu, pengambilan sampel dilakukan dengan teknik random sampling. Sampel yang diambil dalam penelitian ini sebanyak 55 mahasiswa.

Pengumpulan data dilakukan dengan menggunakan dua jenis instrumen, yakni instrumen untuk mengukur gaya belajar yang berupa angket Learning Style Inventory (LSI), serta angket untuk mengukur mathematics self-concept. Angket Learning Style Inventory (LSI) terdiri dari 36 butir pernyataan dengan empat macam pilihan jawaban. Keempat macam pilihan jawaban tersebut merupakan skor yang harus dipilih oleh siswa yang menggambarkan kedekatan setiap pernyataan dengan kondisi pribadi masing-masing, sebagai berikut: skor 4 menggambarkan bahwa pernyataan sangat sesuai dengan kondisi siswa, skor 3 menggambarkan bahwa pernyataan sesuai dengan kondisi siswa, skor 2 menggambarkan bahwa pernyataan agak sesuai dengan kondisi siswa, sedangkan skor 1 menggambarkan bahwa pernyataan kurang sesuai dengan kondisi siswa. Setiap skor tersebut dijumlahkan berdasarkan kelompok pernyataan yang telah ditentukan oleh LSI. Kelompok pernyataan ini diakumulasikan dalam skor yang mencerminkan preferensi seseorang ketika memperoleh sebuah pengetahuan baru.

Sementara itu, angket Mathematics Self-Concept (MSC) disusun dengan memodifikasi angket MSC yang digunakan oleh PISA. Adapun angket MSC yang digunakan PISA berbentuk kuesioner dengan empat pilihan jawaban, yakni SS, S, TS dan STS. Angket MSC berisi respon siswa tentang pernyataan-pernyataan sebagai berikut: (1) saya tidak begitu bagus dalam matematika; (2) saya memperoleh nilai yang bagus dalam matematika; (3) saya sangat cepat belajar matematika; (4) saya selalu percaya bahwa matematika adalah salah satu pelajaran yang paling keren; (5) saya memahami setiap materi matematika, bahkan dalam konsep yang sulit sekalipun. Pengumpulan data telah dilakukan dengan bantuan google form.

\section{HASIL DAN PEMBAHASAN}

Penelitian ini bertujuan untuk mengetahui apakah terdapat pengaruh gaya belajar terhadap minat akademik mahasiswa pada pemilihan program studi serta untuk mengetahui apakah terdapat pengaruh yang signifikan Mathematics Self-Concept (MSC) terhadap minat akademik mahasiswa pada pemilihan program studi. Hasil penelitian ini diambil dari sampel yang dideskripsikan berikut. 
Tabel 1.

Deskripsi sampel penelitian

\begin{tabular}{lcccc}
\hline \multicolumn{1}{c}{ Program studi } & $\boldsymbol{3} \mathbf{3 0}$ & $\mathbf{2 . 7 5}$ s.d. $\mathbf{3 . 5 0}$ & $<\mathbf{2 . 7 5}$ & Total \\
\hline PJKR & 3 & 15 & 1 & 19 \\
Pendidikan Matematika & 9 & 18 & 0 & 27 \\
Administrasi Publik & 1 & 5 & 0 & 6 \\
IImu Komunikasi & 1 & 0 & 0 & 1 \\
$\quad$ Total & 14 & 38 & 1 & 53 \\
\hline
\end{tabular}

Pada Tabel 1 menunjukkan bahwa 51\% sampel penelitian berasal dari program studi pendidikan matematika, 36\% mahasiswa program studi PJKR (Pendidikan Jasmani Kesehatan dan Rekreasi), 11\% mahasiswa program studi administrasi public, dan $2 \%$ mahasiswa program studi ilmu komunikasi. IPK mahasiswa yang menjadi sampel penelitian ini dibagi menjadi tiga kelompok. Persentase mahasiswa yang memiliki IPK antara 2.75 sampai dengan 3.50 adalah $72 \%$.

Penelitian ini menganalisis gaya belajar mahasiswa setiap program studi berdasarkan angket LSI yang diisi oleh setiap mahasiswa. Berikut ini deskripsi gaya belajar setiap mahasiswa pada setiap program studi.

Tabel 2.

Deskripsi gaya belajar

\begin{tabular}{lccccc}
\hline \multicolumn{1}{c}{ Program studi } & \multicolumn{5}{c}{ Gaya belajar } \\
& Diverging & Assimilating & Converging & Accomodating & Total \\
\hline PJKR & 3 & 3 & 2 & 11 & 19 \\
Pendidikan Matematika & 6 & 3 & 2 & 16 & 27 \\
Administrasi Publik & 0 & 0 & 2 & 4 & 6 \\
Ilmu Komunikasi & 1 & 0 & 0 & 0 & 1 \\
Total & 10 & 6 & 6 & 31 & 53 \\
\hline
\end{tabular}

Deskripsi pada Tabel 2 menunjukkan bahwa terdapat 59\% mahasiswa memiliki gaya belajar accomodating, $19 \%$ diverging, $11 \%$ assimilating, dan $11 \%$ converging. Hasil penelitian ini sedikit berbeda dengan penelitian Rais (2017) yang menemukan bahwa terdapat 45\% mahasiswa memiliki gaya belajar accommodating, 10\% yang memiliki gaya belajar diverging, 30\% mahasiswa memiliki gaya belajar converging, dan $15 \%$ mahasiswa memiliki gaya belajar assimilating. Berbeda juga dengan Fuad (2015) yang menemukan jika mahasiswa yang ditelitinya memiliki gaya belajar tipe assimilating $35.8 \%$, diverging $34.6 \%$, accomodating $16.0 \%$, dan converging $13.6 \%$, bahwa $58 \%$ mahasiswa memiliki gaya belajar accomodating.

Baik mahasiswa program studi pendidikan matematika, PJKR maupun administrasi publik, mayoritas memiliki kecenderungan gaya belajar accomodating. Kolb et.al (2000) mengidentifikasikan bahwa mahasiswa yang memiliki kecenderungan gaya belajar accomodating dapat belajar dengan baik menggunakan pengalaman konkret dan eksperimentasi aktif; mereka sering menggunakan strategi trial-and-error daripada membaca instruksinya terlebih dahulu, atau intuisi untuk memecahkan masalah, mereka cenderung untuk mengambil resiko dan masuk ke dalam masalah tersebut, mereka pandai menyesuaikan diri dengan situasi baru. Hal tersebut sesuai dengan karakteristik mahasiswa program studi pendidikan matematika dan PJKR. Program studi matematika menuntut mahasiswa untuk memecahkan masalah matematis dengan cara mencoba mengerjakan soal tersebut secara langsung. Demikian pula dengan mahasiswa program studi PJKR yang lebih banyak praktek dibandingkan dengan teori di kelas. Dengan demikian, sangat beralasan jika kecenderungan gaya belajar mahasiswa kedua program studi adalah accomodating.

Untuk memperoleh analisis yang lebih mendalam, maka gaya belajar mahasiswa dianalisis berdasarkan perolehan IPK mahasiswa pada setiap program studi. Berikut ini deskripsi gaya belajar berdasarkan perolehan IPK mahasiswa pada setiap program studi. 
Tabel 3.

Deskripsi gaya belajar berdasarkan IPK

\begin{tabular}{|c|c|c|c|c|c|c|}
\hline \multirow{2}{*}{ Program studi } & \multirow{2}{*}{ IPK } & \multicolumn{4}{|c|}{ Gaya belajar } & \multirow[t]{2}{*}{ Total } \\
\hline & & Diverging & Assimilating & Converging & Accomodating & \\
\hline \multirow[t]{4}{*}{ PJKR } & $>3.50$ & 0 & 0 & 1 & 2 & 3 \\
\hline & 2.75 s.d. 3.50 & 3 & 2 & 1 & 9 & 15 \\
\hline & $<2.75$ & 0 & 1 & 0 & 0 & 1 \\
\hline & Total 1 & 3 & 3 & 2 & 11 & 19 \\
\hline Administrasi & $>3.50$ & 0 & 0 & 0 & 1 & 1 \\
\hline \multirow{2}{*}{ Publik } & 2.75 s.d. 3.50 & 0 & 0 & 2 & 3 & 5 \\
\hline & Total 2 & 0 & 0 & 2 & 4 & 6 \\
\hline Pendidikan & $>3.50$ & 1 & 1 & 1 & 6 & 9 \\
\hline \multirow{2}{*}{ Matematika } & 2.75 s.d. 3.50 & 5 & 2 & 1 & 10 & 18 \\
\hline & Total 3 & 6 & 3 & 2 & 19 & 27 \\
\hline IImu & $>3.50$ & 1 & 0 & 0 & 0 & 1 \\
\hline Komunikasi & Total 4 & 1 & 0 & 0 & 0 & 1 \\
\hline \multicolumn{2}{|c|}{ Total } & 10 & 6 & 6 & 31 & 53 \\
\hline
\end{tabular}

Tabel 3 menunjukkan bahwa sebagian besar mahasiswa dengan IPK antara 2.75 sampai dengan 3.50 memiliki gaya belajar accomodating. Data ini menunjukkan prestasi yang dimiliki oleh mahasiswa dengan kecenderungan gaya belajar accomodating adalah mahasiswa dengan prestasi yang baik. Rais (2017) mengemukakan bahwa mahasiswa dengan kecenderungan gaya belajar diverging dan accommodating lebih berprestasi pada bidang ilmu sosial. Baik program studi pendidikan matematika maupun PJKR keduanya merupakan program studi yang masuk dalam rumpun ilmu sosial humaniora.

Penelitian ini bertujuan untuk mengetahui pengaruh gaya belajar terhadap minat akademik mahasiswa. Minat akademik yang dimaksud dalam penelitian ini adalah program studi yang menjadi homebased mahasiswa. Analisis statistik yang digunakan adalah uji asosiasi $\chi^{2}$. Berikut ini hipotesis yang digunakan dalam pengolahan data.

$\mathrm{H}_{0}$ : Tidak terdapat pengaruh yang signifikan gaya belajar terhadap minat akademik mahasiswa

$\mathrm{H}_{1}$ : Terdapat pengaruh yang signifikan gaya belajar terhadap minat akademik mahasiswa

Kriteria keputusan yang digunakan dalam uji adalah $\mathrm{H}_{0}$ ditolak jika nilai signifikansi lebih kecil dari taraf signifikansi. Taraf signifikansi yang ditetapkan pada penelitian ini adalah $5 \%$. Berikut ini hasil uji asosiasi gaya belajar terhadap minat akademik mahasiswa dalam memilih program studi.

\section{Tabel 4.}

Uji asosiasi antara gaya belajar dan program studi

\begin{tabular}{lccc}
\hline & Value & $d f$ & Asymptotic significance (2-sided) \\
\hline Pearson Chi-Square & $9.720^{\mathrm{a}}$ & 9 & 0.374 \\
$\mathrm{~N}$ of Valid Cases & 53 & & \\
a. 13 cells $(81.3 \%)$ & have expected count less than 5 . The minimum expected count is .11. \\
\hline
\end{tabular}

Uji asosiasi pada Tabel 4 menunjukkan bahwa nilai signifikansi lebih besar dari taraf signifikansi, maka $\mathrm{H}_{0}$ diterima. Dapat disimpulkan bahwa tidak terdapat pengaruh yang signifikan gaya belajar terhadap minat akademik mahasiswa. Hal tersebut sejalan dengan penelitian ALQahtani \& AlGahtani (2014) yang menemukan bahwa gaya belajar tidak berasosiasi dengan prestasi serta minat khusus mahasiswa. Penelitian Ishak et.al (2017) dan Cimermanova (2018) memperkuat hasil tersebut dengan menemukan bahwa gaya belajar tidak mempengaruhi prestasi belajar. Sementara itu, DePorter \& Hernacki (2000) mengemukakan bahwa gaya belajar adalah kombinasi dari bagaimana seseorang menyerap dan kemudian mengatur serta mengelolah informasi. Mahasiswa perlu memahami gaya belajar untuk mencapai tujuan pembelajaran (Fuad, 2015). Dengan demikian, hasil penelitian ini cukup beralasan untuk mengatakan bahwa program studi yang dipilih oleh mahasiswa tidak mempengaruhi gaya belajar yang mereka miliki.

Analisis selanjutnya adalah mendeskripsikan jenis MSC mahasiswa pada setiap program studi. Deskripsi data jenis MSC mahasiswa pada setiap program studi dapat dilihat pada tabel berikut. 
Tabel 5.

Deskripsi jenis MSC mahasiswa

\begin{tabular}{lccc}
\hline \multicolumn{1}{c}{ Program studi } & \multicolumn{2}{c}{ Jenis MSC } & \multirow{2}{*}{ Total } \\
\hline PJKR & 3 & Negatif & 19 \\
Pendidikan Matematika & 19 & 8 & 27 \\
Administrasi Publik & 2 & 4 & 6 \\
IImu Komunikasi & 0 & 1 & 1 \\
$\quad$ Total & 24 & 29 & 53 \\
\hline
\end{tabular}

Hasil analisis pada Tabel 5 menunjukkan bahwa mayoritas mahasiswa pada program studi pendidikan matematika memiliki MSC yang positif, sedangkan pada program studi PJKR, mayoritas mahasiswanya memiliki MSC negatif. Proporsi mahasiswa yang memiliki MSC positif dan MSC negatif hampir sama. Data ini, sejalan dengan hasil asesmen PISA 2012 (OECD, 2013), yang menyebutkan bahwa mayoritas siswa yang tergabung dalam OECD memiliki MSC negatif. Hasil penelitian yang dilakukan oleh Marsh \& Hau (2003); Marsh (2005); Liu et.al (Adegoke, 2015) menemukan bahwa kemampuan akademik siswa memiliki hubungan yang positif dan signifikan dengan academic selfconcept yang mereka miliki. Marsh \& Shavelson (Adegoke, 2015) menyebutkan bahwa academic selfconcept dapat dibagi menjadi dua domain tertentu, yakni verbal self-concept dan MSC. Dengan demikian, hasil penelitian ini cukup beralasan untuk mengemukakan bahwa mayoritas mahasiswa pada program studi pendidikan matematika memiliki MSC yang positif.

Analisis hasil penelitian dilanjutkan pada tahap mendeskripsikan jenis MSC mahasiswa pada setiap program studi berdasarkan IPK. Berikut ini adalah deskripsi yang diperoleh.

Tabel 6.

Deskripsi jenis MSC berdasarkan IPK

\begin{tabular}{|c|c|c|c|c|}
\hline \multirow{2}{*}{ Program studi } & \multirow[b]{2}{*}{ IPK } & \multicolumn{2}{|c|}{ Jenis MSC } & \multirow{2}{*}{ Tota } \\
\hline & & Positif & Negatif & \\
\hline \multirow{3}{*}{ PJKR } & $>3.50$ & 1 & 2 & 3 \\
\hline & 2.75 s.d. 3.50 & 2 & 13 & 15 \\
\hline & $<2.75$ & 0 & 1 & 1 \\
\hline \multirow[t]{2}{*}{ Administrasi Publik } & $>3.50$ & 0 & 1 & 1 \\
\hline & 2.75 s.d. 3.50 & 2 & 3 & 5 \\
\hline \multirow[t]{2}{*}{ Pendidikan Matematika } & $>3.50$ & 9 & 0 & 9 \\
\hline & 2.75 s.d. 3.50 & 10 & 8 & 18 \\
\hline IImu Komunikasi & $>3.50$ & 0 & 1 & 1 \\
\hline Total & & 24 & 29 & 53 \\
\hline
\end{tabular}

Secara umum, Tabel 6 menunjukkan bahwa mayoritas mahasiswa dengan IPK $>3.50$ memiliki MSC yang positif. Sementara itu, mayoritas mahasiswa dengan IPK 2.75 s.d. 3.50 memiliki MSC negatif. Hasil tersebut sejalan dengan penelitian Kvedere (2012) yang mengemukakan bahwa peningkatan academic self-concept bergantung pada peningkatan prestasi akademiknya dan berlaku sebaliknya. Penelitian ini juga menemukan bahwa seluruh mahasiswa program studi pendidikan matematika dengan IPK > 3.50 memiliki MSC yang positif. Sementara itu, hanya ada satu orang mahasiswa program studi PJKR dengan IPK > 3.50 memiliki MSC positif. Tidak ada satu pun mahasiswa program studi administrasi publik dan ilmu komunikasi dengan IPK $>3.50$ yang memiliki MSC positif. Mayoritas mahasiswa program studi PJKR dengan IPK 2.75 s.d. 3.50 memiliki MSC negatif, sedangkan mayoritas mahasiswa program studi pendidikan matematika dengan IPK 2.75 s.d. 3.50 memiliki MSC positif. Data tersebut memberi gambaran bahwa program studi mempengaruhi jenis MSC setiap mahasiswa. Untuk menguji signifikansi pernyataan tersebut dilakukan uji asosiasi sebagai berikut. 
Tabel 7.

Uji asosiasi MSC dan program studi

\begin{tabular}{lccc}
\hline & Value & Df & Asymptotic significance (2-sided) \\
\hline Pearson Chi-Square & $14.702^{\mathrm{a}}$ & 3 & 0.002 \\
$\mathrm{~N}$ of Valid Cases & 53 & & \\
a. 4 cells $(50.0 \%)$ & have expected count less than & 5. The minimum expected count is 0.45. \\
\hline
\end{tabular}

Nilai asymptotic significance (2-sided) pada Tabel 7 lebih kecil dari taraf signifikansi. Taraf signifikansi yang digunakan pada pengujian ini sebesar 5\%. Dapat disimpulkan bahwa terdapat asosiasi antara program studi dengan MSC yang dimiliki mahasiswa. Hasil uji tersebut sejalan dengan pendapat Nagy et.al (2010) yang mengatakan bahwa MSC dapat menjadi prediktor yang kuat dari prestasi sekolah serta dalam melakukan pilihan pendidikan dan pekerjaan. Hood et.al (2012) menemukan bahwa siswa dengan kemampuan rendah dalam statistika tidak hanya membutuhkan dukungan dalam pengembangan kemampuan kognitifnya tetapi juga self-concept yang dimilikinya. Penelitian Sproesser et.al (2016) menemukan bahwa self-concept siswa berkembang lebih positif pada siswa dengan kemampuan tinggi dalam statistika daripada matematika. Dengan demikian, penelitian ini cukup memiliki alas an bahwa MSC mempengaruhi minat akademik mahasiswa.

\section{KESIMPULAN DAN SARAN}

Berdasarkan hasil penelitian yang telah diuraikan, maka kesimpulan dari penelitian ini adalah (1) tidak terdapat pengaruh yang signifikan gaya belajar terhadap minat akademik mahasiswa pada pemilihan program studi; dan (2) terdapat pengaruh yang signifikan Mathematics Self-Concept (MSC) terhadap minat akademik mahasiswa pada pemilihan program studi. Penelitian ini menemukan bahwa terdapat pengaruh yang signifikan Mathematics Self-Concept (MSC) terhadap minat akademik mahasiswa pada pemilihan program studi MSC dapat dijadikan sebagai gambaran karakteristik mahasiswa setiap program studi. Dengan demikian, setiap program studi sebaiknya memberikan perhatian yang khusus dalam pengembangan self-concept setiap mahasiswanya.

\section{REKOMENDASI}

Hasil penelitian ini dapat menambah referensi bagi penelitian lanjutan yang terkait dengan gaya belajar, Mathematics Self-Concept (MSC) serta minat akademik mahasiswa pada pemilihan program studi. Pengetahuan tentang gaya belajar mahasiswa dapat digunakan untuk memilih model pembelajaran yang tepat untuk memberikan hasil pembelajaran yang optimal. Demikian pula halnya dengan pengetahuan tentang Mathematics Self-Concept (MSC) mahasiswa, akan memberikan refleksi pada mahasiswa tentang konsep diri dan secara tidak langsung akan menambah sisi kepercayaan diri dalam menyelesaikan masalah. Oleh karena itu, pada kesempatan ini penulis memberikan rekomendasi kepada dosen agar sebelum pembelajaran dilaksanakan, lebih baik dilakukan survei mengenai gaya belajar setiap mahasiswa. Selain itu, penelitian lanjutan mengenai gaya belajar, Mathematics Self-Concept (MSC) serta minat akademik mahasiswa pada pemilihan program studi dapat dikaji lebih dalam dengan memperhatikan aspek gender serta faktor sosial ekonomi.

\section{UCAPAN TERIMA KASIH}

Ucapan terima kasih penulis sampaikan kepada Rektor Universitas Subang untuk pendanaan penelitian ini yang berasal dari skema hibah penelitian dosen Universitas Subang.

\section{DAFTAR PUSTAKA}

Adegoke, B. A. (2015). The big-fish-little-pond effect on mathematics self concept of junior school student in academically selective and non-selective schools. Journal of Studies in Education. $5(2), 91-105$.

ALQahtani, D. A., \& Al-Gahtani, S.M. (2014). Assessing learning styles of saudi dental students using kolb's learning style inventory. Journal of Dental Education, 78(6), 927-933. 
Chen, C., Chiu, P., \& Huang, Y. (2015). The learning style-based adaptive learning system architecture. International Journal of Online Pedagogy and Course Design, 5(2), 1-10.

Cimermanova, I. (2018). The effect of learning styles on academic achievement in different forms of teaching. International Journal of Instruction, 11(3), 219-232.

DePorter, B. \& Hernacki, M. (2000). Quantum learning. Bandung: PT Kaifa.

Fuad, A. J. (2015). Gaya belajar kolb dan percepatan belajar. Makalah disajikan dalam Seminar Psikologi \& Kemanusiaan Psychology Forum UMM.

Githua, B. N \& Mwangi, J. G. (2003). Students' mathematics self concept and motivation to learn mathematics: relationship and gender differences among kenya's secondary-school student in nairobi and rift valley provinces. International Journal of Educational Development, 23(5), 487-499.

Hood, M., Creed, P. A., \& Neumann, D. L. (2012). Using The expectancy value model of motivation to understand the relationship between student attitudes and achievement in statistics. Statistics Education Research Journal, 11(2), 72-85.

Ishak, N. B., \& Awang, M. M. (2017). The relationship of student learning styles and achievement in history subject. The International Journal of Social Sciences and Humanities Invention, 4(3), 3372-3377.

Kaminski, D. A., Théroux, P. J., Lister, B. C., \& Gabriele, G. A. (2005). Exploring the link between student learning styles \& grades in an introductory thermal-fluids course. In Proceedings of the 2005 American Society for Engineering Education Annual Conference \& Exposition (pp. 10.508.1-10.508.16).

Kamuche, F. U. (2011). Do learning \& teaching styles affect students performance? an empirical study. Journal of Business \& Economics Research (JBER), 3(9), 35-40.

Kolb, D.A., Boyatzis, R.E. \& Mainemelis, C. (2000). Experiential learning theory: previous research and new directions. Dalam Sternberg, R.J. \& Zhang, L.S. (Eds.). Perspectives on Cognitive, Learning, and Thinking Styles. NJ: Lawrence Erlbaum.

Kolb, A.Y. \& Kolb, D. A. (2005). The kolb learning style inventory version 3.1.

Kvedere, L. (2012). Mathematics self-concept of the $9^{\text {th }}$ grade srudent in latvia. Procedia-Social and Behavioral Science, 116, 2687-2690.

Nagy, G., Watt, H. M. G., Eccles, J.S., Trautwein, U., Ludtke, O., Baumert, J. (2010). The development of students' mathematics self-concept in relation to gender: different countries, different trajectories? Journal of Research on Adolences, 20(2), 482-506.

OECD. (2013). PISA 2012 result: ready to learn: student's engagement, drive and self-belief vol iii. OECD Publishing

Pratiwi, A., Widyarini, I \& Yusainy, C. A. (2010). Konstruksi tes gaya belajar berdasarkan teori belajar eksperiensial david a. kolb. Jurnal Interaktif, 1(1), 1-14.

Rais, M. (2017). Eksplorasi gaya belajar mahasiswa dan kemampuan mengkonsepsi gambar teknik. Jurnal Media Komunikasi Pendidikan teknologi dan Kejuruan, 4(2), 61-68.

Slameto. (2010). Belajar dan faktor-faktor yang mempengaruhinya. Jakarta: PT Rineka Cipta.

Sproesser, U., Engel, J. \& Kuntze, S. (2016). Fostering self-concept and interset for statistics through specific learning environment. Statistics Education Research Journal, 15(1), 28-54.

Wilkinson, T., Boohan, M., \& Stevenson, M. (2013). Does learning style influence academic performance in different forms of assessment?. Journal of Anatomy, 224(3), 304-308. 